context of severe asthma. Identifying the neutrophil survival factor(s) present in this patient group is clearly an important next step and, if targetable, may form the basis of a new therapeutic approach for this difficult-to-treat patient group.

While this study provides further evidence that neutrophil apoptosis may be deregulated in severe asthma, a number of key questions remain. We need to understand the dynamics of cell migration into and out of the airway wall and determine the true residency times and the relative contribution of apoptosis and, indeed, other non-apoptotic death mechanisms such as autophagy, NETosis ${ }^{28}$ and cytolysis in granulocyte clearance. We also need to understand the signals that block apoptosis in the airway wall (yet seemingly not in the airway lumen) and to determine what drives the switch from eosinophil- to neutrophildominated inflammation. Drugs which target the removal rather than the arrival of granulocytes in tissues are now emerging, ${ }^{29}$ and such agents may offer an important adjunct to current asthma treatments.

Funding MRC, Wellcome Trust, Asthma UK, BBSRC, NIHR Cambridge Biomedical Research Centre.

\section{Competing interests None.}

Provenance and peer review Commissioned; not externally peer reviewed.

Thorax 2010:65:665-667.

doi:10.1136/thx.2009.134270

\section{REFERENCES}

1. Serra-Batlles J, Plaza V, Morejón E, et al. Costs of asthma according to the degree of severity. Eur Respir J 1998;12:1322-6.

2. Antonicelli L, Bucca C, Neri M, et al. Asthma severity and medical resource utilisation. Eur Respir J 2004; 23:723-9.

3. Bousquet J, Jeffery PK, Busse WW, et al. Asthma. From bronchoconstriction to airways inflammation and remodeling. Am J Respir Crit Care Med 2000;161:1720-45.
4. Wenzel SE, Szefler SJ, Leung DY, et al. Bronchoscopic evaluation of severe asthma. Persistent inflammation associated with high dose glucocorticoids. Am J Respir Crit Care Med 1997:156:737-43.

5. Macedo P, Hew M, Torrego A, et al. Inflammatory biomarkers in airways of patients with severe asthma compared with non- severe asthma. Clin Exp Allergy 2009;39:1668-76

6. Macdowell AL, Peters SP. Neutrophil in asthma. Curr Allergy Asthma Rep 2007;7:464-8.

7. Woodruff PG, Khashayar R, Lazarus SC, et al. Relationship between airway inflammation, hyperresponsiveness, and obstruction in asthma. J Allergy Clin Immunol 2001;108:753-8.

8. Shaw DE, Berry MA, Hargadon B, et al. Association between neutrophilic airway inflammation and airflow limitation in adults with asthma. Chest 2007:132:1871-5

9. Baines KJ, Simpson JL, Scott RJ, et al. Immune responses of airway neutrophils are impaired in asthma. Exp Lung Res 2009;35:554-69.

10. Baines KJ, Simpson JL, Bowden NA, et al. Differential gene expression and cytokine production from neutrophils in asthma phenotypes. Eur Respir $J$ 2009;35:522-31.

11. Savill JS, Wyllie AH, Henson JE, et al. Macrophage phagocytosis of aging neutrophils in inflammation. Programmed cell death in the neutrophil leads to its recognition by macrophages. J Clin Invest 1989;83:865-75.

12. Hauber HP, Gotfried M, Newman K, et al. Effect of HFA-flunisolide on peripheral lung inflammation in asthma. J Allergy Clin Immunol 2003; 112:58-63

13. Kikuchi S, Kikuchi I, Takaku Y, et al. Neutrophilic inflammation and CXC chemokines in patients with refractory asthma. Int Arch Allergy Immunol 2009;149(Suppl 1):87-93.

14. Wilson RH, Whitehead GS, Nakano $\mathrm{H}$, et al. Allergic sensitization through the airway primes Th17dependent neutrophilia and airway hyperresponsiveness. Am J Respir Crit Care Med 2009:180:720-30

15. Cowburn AS, Condliffe AM, Farahi N, et al. Advances in neutrophil biology: clinical implications. Chest 2008:134:606-12.

16. Ley K, Laudanna C, Cybulsky Ml, et al. Getting to the site of inflammation: the leukocyte adhesion cascade updated. Nat Rev Immunol 2007;7:678-89.

17. van Buul JD, Allingham MJ, Samson T, et al. RhoG regulates endothelial apical cup assembly downstream from ICAM1 engagement and is involved in leukocyte trans-endothelial migration. J Cell Biol 2007;178:1279-93.

18. Kikuchi I, Kikuchi S, Kobayashi T, et al. Eosinophil trans-basement membrane migration induced by interleukin-8 and neutrophils. Am J Respir Cell Mol Biol 2006; 34:760-5.

19. Uller L, Persson CG, Erjefält JS. Resolution of airway disease: removal of inflammatory cells through apoptosis, egression or both? Trends Pharmacol Sci 2006;27:461-6.

20. Araki H, Katayama N, Yamashita Y, et al. Reprogramming of human postmitotic neutrophils into macrophages by growth factors. Blood 2004; 103:2973-80.

21. Savill J, Dransfield I, Gregory C, et al. A blast from the past: clearance of apoptotic cells regulates immune responses. Nat Rev Immunol 2002;12:965-75.

22. Uller $\mathbf{L}$, Persson $\mathrm{CG}$, Källström $\mathrm{L}$, et al. Lung tissue eosinophils may be cleared through luminal entry rather than apoptosis: effects of steroid treatment. Am J Respir Crit Care Med 2001:164: 1948-56.

23. Ward C, Chilvers ER, Lawson MF, et al. NF-KB activation is a critical regulator of human granulocyte apoptosis in vitro. $J$ Biol Chem 1999;274:4309-18.

24. van Raam BJ, Drewniak A, Groenewold V, et al. Granulocyte colony-stimulating factor delays neutrophil apoptosis by inhibition of calpains upstream of caspase-3. Blood 2008;

112:2046-54

25. Cowburn AS, Cadwallader KA, Reed BJ, et al. Role of PI3-kinase-dependent Bad phosphorylation and altered transcription in cytokine-mediated neutrophil survival. Blood 2002;100:2607-16.

26. Altznauer F, Martinelli S, Yousefi $\mathrm{S}$, et al. Inflammation-associated cell cycle-independent block of apoptosis by survivin in terminally differentiated neutrophils. J Exp Med 2004;199:1343-54.

27. Uddin M, Nong G, Ward J, et al. Pro-survival activity for airway neutrophils in severe asthma. Thorax 2010:65:684-89

28. Fuchs TA, Abed U, Goosmann C, et al. Novel cell death program leads to neutrophil extracellular traps. J Cell Biol 2007:176:231-41.

29. Loynes CA, Martin JS, Robertson A, et al. Pivotal advance: pharmacological manipulation of inflammation resolution during spontaneously resolving tissue neutrophilia in the zebrafish. J Leukoc Biol 2010;87:203-12.

\title{
British Thoracic Society Pleural Disease Guidelines - 2010 update
}

\section{Nick Maskell, on behalf of the British Thoracic Society Pleural Disease Guideline Group}

Correspondence to Dr Nick Maskell, North Bristol Lung Centre, Southmead Hospital, Bristol, UK; nick.maskell@bristol.ac.uk

\section{INTRODUCTION}

Pleural disease remains common, affecting over 3000 people per million population each year. It therefore presents a significant contribution to the workload of respiratory physicians. These guidelines attempt to summarise the available evidence to aid the healthcare professional in delivering good quality patient care.

\section{AIMS AND OBJECTIVES OF THE GUIDELINE}

Since the last BTS pleural disease guidelines were published in $2003^{1}$ a large number of good quality primary research papers have been published and the guidelines need to reflect this new data. In addition, there was a need to develop new sections on local anaesthetic (LA) thoracoscopy and thoracic ultrasound to reflect changes in clinical practice. 


\section{AREAS COVERED}

The guideline is divided into the following sections:

1. Investigation of a unilateral pleural effusion in adults

2. Management of spontaneous pneumothorax

3. Management of a malignant pleural effusion

4. Management of pleural infection in adults

5. Local anaesthetic thoracoscopy

6. Chest drain insertion and thoracic ultrasound

\section{METHODOLOGY}

A working party was established with representation from a range of professionals with an interest in pleural disease together with a lay representative. The guidelines are based upon the best available evidence. The methodology followed the criteria as set out by the AGREE collaboration in the document, The AGREE instrument, available on-line at: http://www. agreecollaboration.org/instrument/ The scope and purpose of the guideline had been agreed and defined in consultation with all potential stakeholders representing the medical and nursing professions, patient groups, health management and industry. Guideline members identified and formulated a set of key clinical questions in PICO (T) (Population, Intervention, Comparison, Outcome and Time) format to inform the search strategies for the literature search. The BTS commissioned a bespoke literature search using the search strategies shown in detail on the BTS website (http:// www.brit-thoracic.org.uk). Searches were limited to English and adult literature. 19,425 potential papers were identified by the search. 17393 abstracts were rejected through the criteria outlined above and 2032 full papers were ordered for critical appraisal. A further 591 full papers were rejected because they fell outside the area of focus and scope of the guideline. Formal critical appraisal to assess clinical relevance and scientific rigor of 1441 papers were done independently by at least two guideline reviewers using the SIGN critical appraisal checklists. The guideline reviewers identified an additional 148 papers during the period of guideline development, which were added and critically appraised. The evidence in each study was graded using the SIGN formulated levels of evidence.

This guideline is strengthened by involvement from range of stakeholders and the final guideline is endorsed by 13 Royal Colleges and societies. We hope this will increase its appeal and broaden its use across other specialities.

\section{MAIN RECOMMENDATIONS Patient safety}

The key theme running across these guidelines are ways to improve and maintain patient safety. Issues with chest drain placement were highlighted by, among others, the National Patient Safety Agency alert who reported 12 deaths and 15 cases of serious harm related to chest drain insertion between January 2005 and March 2008. ${ }^{2}{ }^{3}$ Common factors related to the incidents included the lack of experience of the operator, an inadequate level of supervision, failure to follow the manufacturer's instructions, choice of a suboptimal insertion site and poor patient positioning, suboptimal imaging and a lack of familiarity with published guidelines. The use of thoracic ultrasound in pleural procedures (except pneumothorax) has been clearly shown to detect fluid more accurately than by chest radiography, to decrease the incidence of failed aspirations and the incidence of complications, and to be significantly better than clinical examination in choosing a site for safe aspiration or drain insertion. It is therefore highly recommended for all pleural fluid procedures. ${ }^{45}$

\section{Thoracic ultrasound and chest drain insertion}

This new section describes the basics of the thoracic ultrasound technique and includes common findings and pitfalls. It clearly states that at least level 1 competency is required to safely perform independent thoracic ultrasound.

A detailed description of the technique for Seldinger chest drain insertion has also been included. Written consent should be obtained for all chest drain insertions, except in emergency situations and the guideline also includes a standard patient information leaflet for chest drain insertion.

It also recommends that pleural procedures should only be performed in an emergency out side of normal working hours and that chest drains should be inserted in a clean area/room, using full aseptic technique, as it is noted that the iatrogenic infection rate is too high in many published studies. ${ }^{7}$

\section{Investigation of undiagnosed effusions}

This document confirms that there is no place for Abrams needles in the investigation of suspected pleural malignancy due to its poor yield and complication rate. ${ }^{8}$ When pleural tissue is required for diagnostic purposed local anaesthetic thoracoscopy, surgical VATS or a radiology guided pleural biopsy are the methods of choice. The only exception occurs in regions with a high incidence of tuberculosis, as the diagnostic yield with Abrams needles, in TB pleuritis, remains high, but are still not as high as thoracoscopic biopsies. ${ }^{9}$

\section{Pneumothorax}

These guidelines contain new sections on pneumothorax in pregnancy and in patients with cystic fibrosis as well as catamenial pneumothorax. They highlight important issues regarding chest radiograph interpretation with PACS and recommend a diagnostic PACS workstation should be used for image review if making decisions in a patient with a possible pneumothorax. ${ }^{10}$

There is now a new single flow diagram, combining the management pathway for both primary and secondary pneumothorax. This is now simpler for the end-user to use. The BTS has also arranged to send a wall chart of this flow diagram to every NHS accident and emergency department in the UK to help encourage best practice. This initiative has been warmly welcomed by the Society for Acute Medicine.

Other changes include the recognition that in carefully selected, asymptomatic patients with large primary spontaneous pneumothorax, observation alone is a possible treatment option. When intervention is required, simple aspiration remains the initial treatment of choice, but that if this fails once a further attempt at aspiration is unlikely to be helpful and a small bore chest tube should be inserted. ${ }^{10}$

\section{Management of malignant pleural effusions}

These guidelines continue to recommend talc as the most efficacious agent for pleurodesis. However, they now emphasise that calibrated talc should be used to reduce side effects. Small bore chest tubes are recommended first line for pleural drainage as they are more comfortable for patients and no less efficacious. ${ }^{11}$

They also recognise that when the underlying lung is trapped, a previous pleurodesis attempt has failed or when pleural fluid production is very high, a tunnelled pleural catheter might be appropriate. $^{11}$

\section{Local anaesthetic thoracoscopy}

These new guidelines reflect the changing practice in the UK, which is now more in line with the rest of Europe reflecting easier access to thoracoscopy as a safe and 
reliable way of obtaining a histological diagnosis and performing a pleurodesis. They discuss the current literature in detail and also provide a web-based repository for how the procedure is performed. $^{12}$

\section{Pleural infection}

This guideline emphasises the continuing high morbidity and mortality related to this condition. It continues to recommend chest tube drainage for sizeable effusions with $\mathrm{pH}<7.2$ or loculation in the context of clinical signs of infection/sepsis. It states the lack of evidence for a large chest tube being more efficacious than a small one and notes patients are more comfortable with a smaller tube. Differences between community acquired and hospital acquired pleural infection is also highlighted with a need for different empirical antibiotics at presentation. ${ }^{13}$

\section{Future directions and audit}

It is recognised that there remain number of key unanswered questions pertaining to pleural disease and its management, which require study. Some of these are listed at the end of guideline and include use of tunnelled indwelling pleural catheters in the management of chronic end stage non malignant pleural effusions, the role and position of novel biomarkers in the diagnostic pathway for undiagnosed pleural effusions and the efficacy of talc poudrage versus talc slurry in malignant effusions.

Finally, the importance of audit is emphasised in the management of pleural disease and BTS has developed an audit tool for pleural procedures which is available via the online BTS audit system. ${ }^{14}$

\section{Concluding comments}

The Guideline Group hope that these guidelines will prove both popular and useful in assisting physicians managing patients with pleural disease. We recognise that that the literature pertaining to pleural disease is not always of high quality but hope that we have used the data available to produce a robust evidence based guideline which safeguards patients and drives up standards in pleural disease management. We also hope that greater engagement and endorsement from other medical specialities will broaden its appeal.

British Thoracic Society Pleural Disease Guideline Group

Dr Nick Maskell, Chair

Dr Nabeel Ali

Dr George Antunes

Dr Anthony Arnold

Professor Robert Davies

Dr Chris Davies

Dr Fergus Gleeson

Dr John Harvey

Dr Diane Laws

Professor YC Gary Lee

Dr Edmund Neville

Dr Gerrard Phillips

Dr Richard Teoh

Dr Naj Rahman

Dr Helen Davies

Dr Tom Havelock

Dr Clare Hooper

Dr Andrew MacDuff

Dr Mark Roberts

\section{Competing interests None.}

Provenance and peer review Commissioned; not externally peer reviewed.

Thorax 2010;65:667-669.

doi:10.1136/thx.2010.140236

\section{REFERENCES}

1. BTS Guidelines for the management of pleural disease. Thorax 2003;58(Suppl 2).

2. National Patient Safety Agency. Risks of chest drain insertion. NPSA 2008/RRR003 (accessed 15 May 2008)

3. Harris A, O'Driscoll B, Turkington P. Survey of major complications of intercostal chest drain insertion in the UK. Postgrad Med J 2010;86:68-72.

4. O'Moore PV, Mueller PR, Simeone JF, et al. Sonographic guidance in diagnostic and therapeutic nterventions in the pleural space. AJR Am J Roentgenol 1987;149:1-5.

5. Diacon $\mathbf{A H}$, Brutsche MH, Soler M. Accuracy of pleural puncture sites. A prospective comparison of clinical examination with ultrasound. Chest 2003;123:436-41.

6. Royal College of Radiologists. Ultrasound training recommendations for medical and surgical specialties. London: Royal College of Radiologists. http://www.rcr.ac.uk.

7. Havelock T, Teoh R, Laws D, et al. Pleural procedures and thoracic ultrasound-British Thoracic Society pleural disease guideline. Thorax 2010; 65(Suppl 2):ii61-ii76.

8. Maskell NA, Gleeson FV, Davies RJO. Standard pleural biopsy versus CT-guided cutting-needle biopsy for diagnosis of malignant disease in pleural effusions: a randomised controlled trial. Lancet 2003:361:1326-30.

9. Hooper C, Lee YCG, Maskell NA. Investigation of a unilateral pleural effusion in adults-British Thoracic Society pleural disease guideline. Thorax 2010;65(Suppl 2):ii4-ii17.

10. MacDuff A, Arnold A, Harvey J. Management of spontaneous pneumothorax-British Thoracic Society pleural disease guideline. Thorax 2010;65(Suppl 2): ii18-ii31.

11. Roberts ME, Neville E, Berrisford RG, et al. Management of a malignant pleural effusion-British Thoracic Society pleural disease guideline. Thorax 2010;65(Suppl 2):ii32-ii40.

12. Rahman NM, Ali NJ, Brown G, et al. Local anaesthetic thoracoscopy-British Thoracic Society pleural disease guideline. Thorax 2010;65(Suppl 2): iï4-ii60.

13. Davies HE, Davies RJO, Davies CWH. Management of pleural infection in adults-British Thoracic Society pleural disease guideline. Thorax 2010;65(Suppl 2): ii41-ii53.

14. BTS Audit tools. https://audits.brit-thoracic.org.uk/. 